\title{
LAND VALUE AND LAND PLANNING: BRITISH LEGISLATION AND AMERICAN PROSPECTS
}

THE market as a means of coordinating the decisions of individual land owners has failed to produce a satisfactory pattern of land use for the modern community. ${ }^{1}$ Slums, blight, traffic congestion, over-crowding at the center and disorganization in the suburbs, combined with indiscriminate mingling of business, industry, and housing, have everywhere followed uncontrolled urban growth. ${ }^{2}$ Deliberate community decision, therefore, is gradually replacing automatic operation of the market as the determinant of the land use pattern in both Great Britain and the United States. Municipal and regional planning procedures are being developed for the formulation and execution of those decisions. The Town and Country Planning Act of $1947^{3}$ is the most recent step in this development in Great Britain.

Community planning seeks to establish a pattern of land use which will enable the community to achieve its basic values. ${ }^{4}$ Clarification of these values and public agreement on the general characteristics of a land use pattern consonant with them form the foundation of community planning and shape specific planning techniques. These techniques include determination of overall community design, regulation of private land use to secure conformity with the design, and public ownership and development where regulation of private use proves inadequate. ${ }^{5}$

But even when community planning determines the land use pattern, so long as land is privately owned and exchanged the land market will survive. And land values in that market may be affected by community measures for control of land use in such a way as to complicate reconciliation of

1. "In no field, outside perhaps of money and credit, is the case for collective modification of the results brought about by free enterprise stronger than in [the field of land usel." 155 Economist 258 (1948). And see Fisher, Economic Aspect of Zoning Blighted Areas, and Rehabilitation Laws, 32 Amer. Econ. Rev. 331, 339-40 (1942). For explanations of why the market has failed in this respect, see Polanyi, The Great Transformation (1944); International City Managers Ass'n, Local Planning Adninistration 12-14 (2d ed. 1948).

2. See, e.g., Munford, The Culture of Cities 143-299 (1938); U.S. National Resources Committee, Our Cities 55-69 (1937). For an analysis of urban chaos in Great Britain, see Royal Commission on the Distribution of the Industrial Population, REPORT 51-97, 158-170 (Cmd. 6153, 1940).

3. $10 \& 11$ GEo. 6, c. 51 (cited hereafter as TCPA). Although the Act was passed as a Labor Government measure, it owes little to socialist doctrine and enjoys wide non-socialist support. See Monson, Development and Practice of British Planning Law, 44 ILL. L. Rev. 779 (1950); Note, 60 HARV. L. REv. 800 (1947).

4. See McDougal, Municipal Land Policy and Control, 242 ANnals 88-90 (1945). For an imaginative demonstration of the interdependence of the land use pattern and the total culture of the community, see Goodman, Communitas (1947).

5. This analytical division of the community planning process follows, with some omissions, that adopted in MicDougal \& Haber, Property, Wealth, LaND 751-896 (1948). 
individual and community interests. American planning law has heretofore relegated this difficulty to the background. The British Town and Country Planning Act of 1947 meets it squarely with an original solution.

A comparison of British and American planning goals and techniques, an analysis of the British approach to the conflict between planning and the land market, and an examination of alternative American solutions, may serve to clarify American problems.

\section{Planning Goals}

\section{The British EXPERIENCE}

Substantial public agreement on the community pattern to be achieved through planning had already developed in Great Britain before the passage of the Town and Country Planning Act of 1947. The decay of the existing urban culture which had become apparent during the depression, ${ }^{6}$ and the need for extensive reconstruction following wartime damage, ${ }^{7}$ had stimulated public concern. Four government studies ${ }^{8}$ and a series of imaginative postwar community plans ${ }^{9}$ crystallized agreement on a more desirable urban pattern.

6. The drop in general prosperity in the early thirties threw into harsh relief the economic and social deficiencies of the older industrial centers and turned them into "depressed areas," foci of poverty and unemployment. Flight from these cities brought a shift in industrial location to the already congested metropolitan areas of London and Manchester. The problems caused by this shift were the starting point of the Barlow Commission's inquiry. See, Royal Commission on the Distribution of the Industrial Population, REPoRt 3 (Cmd. 6153, 1940); 129 Economist 415-16 (1937); 128 EconoMist 64-5 (1937).

7. Not more than $5 \%$ of all urban housing was destroyed by enemy action. Woodbury, Britain Begins to Rebuild Her Cities, 41 Amer. Pol. Scr. Rev. 901, 902 (1947). This destruction, however, was a powerf ul psychological stimulus to ambitious redevelopment programs. "What made this country planning conscious was the bombing of our cities in 1940-1. This let in daylight in a double sense. People began to speculate on better things they might build on the acres of rubble; and from this they began to speculate how the out-of-date areas left unbombed might be replanned. It was just a lucky coincidence that when they first asked such questions, there was the Barlow report, handy on the shelf, with the answer." Osborn, Greenbelt Cities 47 (1946).

8. The Royal Commission on the Distribution of the Industrial Population, appointed in 1937 by the Chamberlain Government under the chairmanship of Sir Montague Barlow, treated the initial problem of proper location of industry as a jumping-off point for a general social, economic, and strategic study of the British urban pattern and its reform. (Its report, Cmd. 6153, issued in 1940, is cited hereinafter as the BARLOW REPORT). The Committee on Land Utilization in Rural Areas, appointed in 1941 under the leadership of Lord Justice Scott, considered, in addition to specifically rural problems, the relation of urban growth to the supply of food-producing agricultural land. (Its report, Cmd. 6378, was completed in 1942). The Expert Committee on Compensation and Betterment, appointed in 1940 and headed by Mr. Justice Uthwatt, adopted the planning goals of the BARLOW REPORT and concentrated on the problem of land planning and land values. (Its report, Cmd. 6386, 1942, is cited hereinafter as Uthwart REPORT). Finally, the New Towns Committee, established in 1944 under the chairmanship of Lord Reith, studied means of decentralizing large urban concentrations by the establishment of satellite towns. (Its report, Cmd. 6876, was issued in 1946).

9. Starting in 1942 a number of municipal councils, either alone or through regional 
The British regard this pattern as designed to accomplish two ends. First, it is aimed at preserving the mutual accessibility of industrial plants, commercial centers and residences of workers and consumers on which the modern economy depends. Second, it is designed to give every residence the privacy, access to light, air, open space and recreational facilities, and the framework for common neighborhood life which are considered necessary for personal and social well-being. ${ }^{10}$

The British realize that attainment of these goals entails fundamental reorganization of the existing urban pattern. Their plans call for reversing the trend toward concentration of industry and commerce in overgrown metropolitan centers. ${ }^{11}$ With the easing of this pressure, the suburban sprawl of the great cities is to be halted by a surrounding "greenbelt" or system of "greenwedges" restricted to agricultural or recreational use. ${ }^{12}$ Starting with the worst slums and blighted sections, the centers of existing cities are to be replanned and where necessary rebuilt with radically decreased density, more open space, and integrated neighborhood organization. ${ }^{13}$ Industrial

committees, commissioned planners to prepare long range programs for post-war reconstruction. These plans, which are to be distinguished both from statutory planning schemes under existing planning legislation, see notes 18-19 infra, and from legally binding development plans under the Town and Country Planning Act of 1947, see note 21 infra, were long range proposals showing what might be accomplished in a generation or more. Representative plans are Abercrombie,Greater London Plan 1944 (1945); Watson \& Abercrombie, a Plan for Plymouth (1943); Abercrombie, Onfens \& Mealand, a Plan for B.th (1945): Lutyens \& Abercrombie, A Plan for Kingston Upon Hull (1945); Thompson. Mierseyside Plan, 1944 (1945). By 1947. sixty-seven British cities had plans of this sort. Monson, supra note 3 , at 797 .

These plans aroused great public enthusiasm and their broader goals seem to have gained almost universal support, doubts being expressed only as to the immediate availability of resources to carry them into execution. See, e.g., The Plymouth Plan, 146 Economist 562 (1944); Castles in the Air, 147 Economist 793 (1944); Manchester and Middlesbrough. 149 Econonist 117 (1945). See also Felton, Democracy in Town and Country Planning. 20 PoL. Q. 74, 78 (1949); Woodbury, supra note 7, at 905-6; Monson, supra note 3, at 798.

10. The requirements of a desirable urban pattern are not expressly formulated at this high level of abstraction in the Barlow or Scott reports or in the city plans cited in note 9 supra. But this is a fair statement of the assumptions underlying the more concrete proposals for urban decentralization contained in the BARLOW REPORT and in the city plans. See, e.g., Barlow Report 49, 51-97; Abercrombie, Greater London Plan 1944, 4-12, 30-31, 110-121 (1945).

11. B.ARLOw REPORT 195-201. This was the principal recommendation of the Barlow commission.

"The Planning Bill (of 1944) assumes that there will be dispersion of population and industry from congested cities. The need for their dispersal is not merely the one accepted principle of modern town planning-it is common ground between all parties." 147 EcoNoMIST 634 (1944).

12. See, e.g., Barlow Report 136; Abercrombie, Greater london Plan 1944, 8, 24-26, 35-6 (1945); Thompson, Merseyside Plan 1944, 4-5 (1945); Watson \& Abercrombie, A Plan for Plyajouth 41, 43-48 (1943).

13. See, e.g., Barlow Report 84; Abercrombie. Greater London Plan 1944, 30-38, 110-120 (1945); Lutyens \& Abercrombie, A Plan for Kingston UpoN Hull 49-60 (1945); Thompson, Merseyside Plan 1944, 14-21 (1944). 
and commercial facilities for which central location is essential are to be laid out in a more efficient pattern and, where necessary, segregated from residential areas. ${ }^{14}$ People and industries displaced by this deconcentration are to be accommodated in "satellite" communities beyond the greenbelt, which will be working as well as living places for their inhabitants, but which will maintain social and commercial connection with the central city. ${ }^{15}$

The development of concrete programs to implement these goals is just beginning. One of Parliament's first steps was to pass the Town and Country Planning Act of 1947, providing the basic legal framework within which urban reorganization is to be carried out.

\section{Determination of Community Design and Control of Land Use}

The British Town and Country Planning Act of 1947 builds on forty years of experience in determining community design and controlling land use in the service of goals more modest than urban reorganization. ${ }^{16}$ American planning began with piecemeal control of a few aspects of land use $;^{17}$ early British legislation, on the other hand, applied local "planning schemes," with a fairly complete set of controls, to open land in the course of development in $1909,{ }^{18}$ and extended them to include built-up areas in 1932. ${ }^{19}$ By 1942 completed or prospective planning schemes covered about half of Great Britain. ${ }^{20}$

14. See, e.g., Abercrombie, Greater London Plan 1944, 38-85 (1945); Watson \& Abercrombie, A Plan for Plymouth 55-63 (1943); Lutyens \& Abercrombie, A Plan FOR KINGSTON UPON HULL 65-9 (1945).

15. See Barlow Rerort 127-36; Abercrombie, Greater London Plan 1944, 36-37 (1945); Monson, supra note 3, at 802-3. For an extended discussion of the satellite town idea, which is fifty years old in Great Britain, see Osborn, Green Bedt Citres (1946). The New Towns Act, 1946, 9 \& 10 GEo. 6, c. 68, provides for the establishment, for each "new Town," of a government corporation which buys land, constructs housing and community facilities, and eventually turns over land and buildings to a cooperative organization of the residents. The number of people who will eventually be displaced by the de-congestion of existing cities and accommodated in new towns or major extensions of existing small towns has been estimated at from two and a half to three million. NEw Towns CosmirTeE, Final REPORT (Cmd. 6876, 1946), cited in Monson, supra note 3, at 802.

16. "It is no part of statutory planning, as at present existing, to check or to encourage a local or regional growth of population. . . . It may, therefore, be said that while present statutory town-planning tends towards producing a more pleasant, healthier and more convenient local environment, it is not adapted to check the spread of great towns or agglomerations, nor . . . to arrest the tendency to increasing central density and traffic congestion." BARLOW REPORT 104-5.

17. See note 90 infra.

18. Housing, Town Planning, etc., Act, 1909, 9 Evw. 7, c. 44, §§ 54-67.

19. Town and Country Planning Act, 1932, $22 \& 23$ GEo. 5, c. 48, $\$ \$ 1,11-13$.

20. In June $1942,3 \%$ of the area of Great Britain was covered by completed planning schemes, and about $48 \%$ by "resolutions to prepare schemes." UTHWATT REPORT 9 . In the latter case, interim land use controls were exercised while schemes were being drafted. The Barlow Commission found that complete or interim controls extended over most areas where extensive development was expected. BARLOw REPORT 108. 
The 1947 Act places the initial determination of specific community design at the local level. Local government units prepare a "development plan" for their community, indicating proposed land use and the stages by which development should be carried out. ${ }^{21}$ The plan, based on a physical survey and a study of the community's economic and social needs, is adopted, after a public hearing, by the local legislative body. Plans are reviewed at five year intervals. ${ }^{22}$ Where the area to be planned as a unit does not coincide with existing local government boundaries, the Minister of Town and Country Planning may transfer local planning functions to a joint planning board made up of members appointed by the component legislative bodies. ${ }^{23}$

The framers of the Act recognized that redistribution of industry, limitation of urban expansion, and encouragement of urban decentralization could not be attained under disconnected local plans. ${ }^{24}$ Accordingly, they entrusted the coordination of local development plans to a national Ministry of Town and Country Planning. The Ministry must approve local plans before they become effective ${ }^{25}$ and may require modification of a plan before approving it.

The Act provides for regulation of private land use by requiring that landowners obtain "development permission" from the local authority before undertaking substantial building operations or a material change of land use. ${ }^{26}$ Under the Act proper, unless an owner has obtained permission, he

21. TCPA $\$ 5(1)(2)(3)$. Unless a joint planning board is extablished, see note 23 infra, the governmental units carrying out local planning functions are the councils of counties and of county boroughs, called in the Act "local planning authorities." Id. $\$ 4(1)$. If a local authority fails to prepare a plan, the Ministry of Town and Country Planning may step in and do so. $I d . \$ 7(1)$.

The development plan may "define the sites of proposed roads, public and other buildings and works, airfields, parks, pleasure grounds, nature reserves and other open spaces, or allocate areas of land for use for agricultural, residential, industrial or other purposes of any class specified in the plan." Id. $\$ 5(2)$ (a). It should also designate the areas which the authority plans to purchase and redevelop in the following ten-year period. $I d . \S 5(2)$ (b), 5(3). And see note 33 infra.

22. TCPA $\S 6(1)$. Development plans are to program future development in four successive five-year stages. The plan for the current stage governs planning authority action; plans for later stages must be reviewed at the end of each period before they go into effect. Thus periodic review and re-survey make planning a continuous process rather than a fixed blueprint. See Ministry of Town and Country Planning Circular 59 (1948); Monson, supra note 3 , at $799-801$.

23. TCPA $\$ 4(2)(3)$, and First Schedule (1). Unless the county councils consent to formation of a joint board, the Minister must hold a local hearing and then submit his order to Parliament, which may annul it by resolution within forty days.

24. See BarLow REPort 104-5. And see the statement of H.M. Silkin introducing the Bill on its second reading in Parliament, 432 H.C. DEB. 956 (5th ser. 1947).

25. TCPA $\S 5(1)(4)$. Prior to acting on a development plan, the Minister must consider any objections that are submitted, and may hold local hearings for this purpose. $I d$. $\$ 10(2)(3)$. Provisions of a development plan are subject to judicial review only when they exceed the powers granted by the Act, or when the procedure established by the Act has not been followed, to the prejudice of the complaining party. Id. $\$ 11(2)(3)$.

26. Development for which permission is required includes, with specified exceptions, 
can do no more than make interior alterations, devote land or buildings within the "curtilage" of a dwelling to uses incidental to residence, use land or buildings for agriculture, or change existing buildings from one use to another within a particular "use class." 27 By regulation the Minister may free additional types of development from the permission requirement; ${ }^{28}$ present regulations exempt extension of an existing residential or industrial building which increases its volume by less than $10 \% .{ }^{29}$ For all other development, the local authority grants or withholds permission in accordance with the provisions of the local development plan. ${ }^{30}$ Furthermore, it may

see note 28 infra, "carrying out of building, engineering, mining or other operations in, on, over, or under land, or the making of any material change in the use of any buildings or other land." TCPA \$ 12(2).

If the owner carries out development without permission, the local authority may, at any time within four years, order him to remove the buildings or discontinue the use and restore the property to its previous condition. $I d$. $\$ 23$. Failure to comply with the order is punishable by fine. $I d . \S 24(3)$. The authority may also enter upon the property and remove the offending development at the violator's expense. $I d . \$ 24(1)$.

27. TCPA $\$ 12(2)(a)(d)(e)(f)$. The interior alterations allowed without permission do not include conversion of a single to a multiple family dwelling. $I d . \S 12(3)$. Nor can building exteriors be used for advertising without permission. $I d . \S 12(4)$.

"Use classes" are extablished by regulations of the Ministry of Town and Country Planning. Current regulations grant some latitude for changes of use when substantial new building is not involved. For example, premises used as a retail shop may be converted to another type of retail shop or to a restaurant without planning permission. Other typical classes within which uses are interchangeable are "use as an office for any purpose" and "use as a light industrial building." There are at present eighteen classes in all. Town and Country Planning (Use Classes) Order, 1950 (S.I. 1950 No. 1131), cited in 94 SoL. J. 526 (1950).

28. TCPA $\S 13(1)(a)(2)(3)$. Those regulations, called "development orders," must be submitted to Parliament, which may veto them within a forty-day period. Id. $\$ 13(5)$.

29. Town and Country Planning General Development Order, 1950 (S.I. 1950 No. 728), First Schedule, Classes I \& VIII.

30. The local planning authority may either refuse permission, or grant it conditionally or unconditionally. Id. $\$ \$ 13(1)(b), 14$. An adverse decision of the local authority may be appealed to the Minister, who considers the matter de novo. $I d . \$ 16$. In reaching their decisions, local authorities and the Minister must "have regard to the provisions of the development plan, so far as material thereto, and to any other material considerations." Under this standard the Minister has occasionally granted permission even though the development is contrary to plan, or, conversely, refused permission despite the fact that the plan would permit the development. The plan, however, appears to be decisive except where there are unusual factors favoring departure from it. See Brown, Principles and Practice in Planning Appeal Decisions, J. of Planning Law 88, 94-7 (1950).

The generality of the statutory language is thought to preclude effective judicial review of development permissions. See White, Private Rights and Ministerial Action, J. of PLaNNING LAW 32, 177 (1948). Such breadth of administrative discretion seems less a peculiarity of the Town and Country Planning Act than a general characteristic of British administrative law and practice. "The fundamental principle of English administrative law is that departmental policy is a matter for Parliament, and the Courts will not interfere with it. Thus the Courts will not arrogate to themselves a power to hear appeals 'on the merits' from a decision of a Ministry, and it is rare to find such an appeal provided by statute." Ibid. And see generally Schwartz, Latw AND the Executive IN GrEat Britain (1949). 
order the termination of an existing use not conforming to the development plan. ${ }^{31}$ In this case it must compensate the owner for loss of land value, damages resulting from disturbance of enjoyment, and expenses incurred in making the required change. ${ }^{32}$

The Town and Country Planning Act contemplates extensive municipal ownership of land. Local planning authorities may acquire land by agreement or compulsory purchase wherever needed for comprehensive redevelopment of badly planned or blighted areas, or for any other purpose provided in the development plan. ${ }^{33}$ Such acquisitions are financed by local authorities with the aid of Exchequer grants. ${ }^{34}$ The municipality may redevelop the land itself or resell it to private developers after replanning. ${ }^{35}$

\section{The Land Value Problem}

The most ingenious and suggestive feature of the Town and Country Planning Act of 1947 is its financial technique for equalizing the shift in

31. TCPA $\$ 26$.

32. TCPA $\$ 27(1)$. Such compensation may be financed by the local authorities with the aid of Exchequer grants. Id. $\$ 94(1)$ (a).

The Act also piovides another means of relieving the owner when the requirements of a development plan impose special hardship on him. If either an order to discontinue an existing use or a refusal of development permission for a new use leaves the land "incapable of reasonably beneficial use" for any purpose which is permitted, the owner may request the local authority to purchase the land outright. This request, or "purchase notice," is referred to the Minister of Town and Country Planning; if the Minister finds that all reasonably beneficial use is indeed precluded, he must either reverse the refusal of permission (or the order to discontinue) or order the local authority to purchase. Id. $\$ \$ 27(3), 19$. Purchase might, for example, be required where permission for any but residential development is refused on a piece of land too small to hold a house. When a local authority is ordered to purchase land in this manner, it pays the same price that it pays on so-called "compulsory purchase," i.e., when it orders a landowner to sell his land to the authority. See note 62 infra.

33. Compulsory acquisition of land for planning purposes is carried out in two steps. First, the local development plan may designate as "subject to compulsory acquisition" areas "which should be developed or redeveloped as a whole . . . for the purpose of dealing satisfactorily with extensive war damage or conditions of bad layout or obsolete development, or for the purpose of providing for the relocation of population or industry . . or for any other purpose specified in the plan," TCPA $\$ 5(3)$, or areas "which ought . . to be subject to compulsory acquisition for the purpose of securing its use in the manner proposed by the plan." Id. $\$ 5(2)$ (c)(ii). Such designation is subject to Ministerial approval, with the additional proviso that land may be designated only if acquisition is likely to take place within ten years. $I d . \S 5(4)$ (a). Second, the local planning authority or a subordinate local government unit may, from time to time, acquire land so designated either by compulsory purchase or by agreement with the private owners. $I d$. $\$ 38,40$. If the local authority does not purchase "designated" land within twelve years, the owner can force it to do so or to remove the "designation." Id. $\$ 9$. This two-step condemnation system is designed to reduce the danger that uncertainty as to future public acquisitions will inhibit private development.

34. TCPA §93. Such exchequer grants may amount to $90 \%$ of the annual costs incurred by the local authority in borrowing to defray its redevelopment expenditures. $I d$. $\$ 93(5)$.

35. TCPA $\$ 44$. 
land values produced by community land use control. Though the implications of this equalization technique are revolutionary, it is the product of a long struggle with the problem of shifting land values.

The value of land is theoretically equal to the present value of the future income which can be realized from its use; its market value reflects the expectations of buyers and sellers as to this future income. ${ }^{36}$ Since income from land varies widely according to its use, and since use is partially determined by location in the physical pattern of the community, any public measure which changes the subsequent pattern of the community changes the present value of some land. In analysing this effect, a distinction may be made between "existing use value" of land, defined as its present value on the assumption that its present use will continue, and "development value," defined as that part of its present value attributable to the expectation of future change to a more profitable use.

Community regulation of land use shifts development value. Where regulation restricts to a particular use land whose value has been based on the expectation of a different and more profitable use, it reduces the development value of that land. ${ }^{37}$ But it increases the development value of other land not so restricted, because elimination of alternative locations increases the probability that the other land will in fact be devoted to the more profitable use. ${ }^{38}$ If the rate as distinct from the direction of change to this use throughout the community persists unaltered by the regulation, and if development values reflect realistic expectations of this rate, the total increases and decreases in value will balance, and value is merely shifted by community action. ${ }^{39}$ The magnitude of the shift depends upon the difference

36. See Weimer and Hoyt, Principles of Urban Real Estate 150 (1939).

37. For example, a growing community is usually surrounded by a belt of land, presently devoted to agricultural or other low-density use, which its owners expect to put to more profitable residential use as the community expands. This expectation produces present land values throughout the belt much higher than they would be if based on agricultural use only. A regulation prohibiting residential use in a section of the belt would reduce the development value of this section. See UTHWATT REPORT 15-16.

38. Ibid. As used in this comment, the phrase "shifting value" means only the type of shift here described. It was this phenomenon which was analyzed by British commentators and dealt with in the Town and Country Planning Act of 1947 . But community action may cause other types of land value change as well. Prohibition of an incompatible use on one piece of land may increase the value of surrounding land for its existing use. See Schmutz, Economic Effects of Zoning, 155 (II) ANNals 172, 173 (1931). Community permission for a profitable use where factual probabilities of this use are slight may itself heighten the expectations of landowners and therefore produce inflated development values. See Fisher, Economic Aspects of Zoning, Blighted Areas, and Rehabilitation Laws, 32 Ar. Econ. REv. 331, 333-4 (1942). The emphasis of American regulation on the problems of mixed incompatible land uses, and the frequency with which it has reinforced rather than disappointed landowner expectations, have made such relationships more noticeable in the United States than is "shifting value." See notes 112, 114 infra.

39. "The public control of the use of land ... necessarily has the effect of shifting land values: in other words, it increases the value of some land and decreases the value of other land, but it does not destroy land values. Neither the total demand for development 
between the pattern set by the community and the pattern which buyers and sellers had expected in the absence of regulation. ${ }^{40}$

Prior to the 1947 Act British planning legislation provided public compensation for land values lost as a result of local planning schemes, ${ }^{41}$ and public recovery of "betterment" from corresponding increases in land values. ${ }^{42}$ By 1937 these compensation and betterment provisions had been recognized as a major obstacle to urban reorganization. ${ }^{43}$ The amount of compensation was subject to gross inflation arising from over-optimistic expectations of future development. The actual prospect of development, against which such expectations may be corrected, can be estimated only for an entire area of community growth. But the 1932 Planning Act, like its predecessors, provided only for separate calculation of compensation for each owner. The sum of development values calculated individually might, therefore, be double or triple the value which would be added over the entire area by the actual rate of future development. ${ }^{44}$ In addition, the betterment charges which should balance compensation payments proved virtually impossible to assess or collect. No feasible method could be found for determining what portion of the actual increase in value of particular land could be attributed to a

not its average annual rate is materially effected, if at all, by planning ordinances." UTHWATT REPORT 15.

The analysis in the UTHWATT REPORT articulates only one assumption governing the balance of land value increases and decreases-namely, that the rate of development remain substantially unaltered. But the other assumption, that initial development values be based on realistic expectations of this rate, is equally important. If, for example. development values should reflect private expectations of a rate of development which is four times the actual rate, a mere doubling of the actual prospect of development on particular land might cause no appreciable increase in value.

40. For example, if regulation allows residential use in all areas where values are based on expectation of such use, no value is shifted.

41. Housing, Town Planning, etc., Act, 1909, 9 Evw. 7 c. 44, $\S 58$; Town and Country Planning Act, 1932, $22 \& 23$ GEo. 5, c. 48, $\$ \$ 18,19$. The 1932 Act provided that "any person whose property is injuriously affected by the coming into operation of any provision contained in a scheme . . . shall . . . be entitled to recover as compensation . . . the amount by which his property is decreased in value, and . . . the amount of any resulting injury to [his] trade or business or profession." Id. $\$ 18(1)$. However, with the approval of the Minister of Health, compensation could be omitted in the case of specified types of regulation. Id. $\$ 19(1)(2)$.

42. The 1932 Act provided: "Where by the coming into operation of any provision contained in a scheme . . . any property is increased in value, the responsible authority may ... recover from the person whose property is so increased in value an amount not exceeding seventy-five per cent of the amount of that increase." Id. $\$ 21$. For a similar provision in the Housing, Town Planning, etc., Act, 1909, see 9 EDw. 7 c. 44, $\$ 58(3)$.

43. See BARLOW REPORT 112-17.

44. See BarLow Refort 115; Uthwatr REPoRt 14-15, 40. The estimate of double or triple inflation of development values was apparently made by the Uthwatt Committee on the basis of evidence of past experience with land valuation for tax and condemnation purposes. Ibid. Its validity was never tested by actual experience with compensation, since local authorities avoided large scale compensation liability by keeping their planning schemes unambitious; see page 121 infra. 
planning scheme, and how much to other influences. ${ }^{45}$ In practice planning schemes avoided these financial obstacles by repeating the previously existing pattern of expected land use instead of working toward major reforms in the pattern. ${ }^{46}$ Shifting land value, and therefore liability for compensation, was kept to a minimum. At the same time urban reorganization was blocked.

During the decade before 1947, several methods of cutting the Gordian knot of compensation and betterment were considered. The Uthwatt committee, on whose work the financial provisions of the 1947 Act are largely based, found that complete elimination of compensation would be consonant with common law principles. ${ }^{47}$ It rejected this expedient, however, as imposing excessive and unequal hardship on those landowners adversely affected by shifting values. ${ }^{4 \$}$ It recognized nationalization of all land as a theoretically ideal solution for the shifting value problem, but did not consider it a practical possibility. ${ }^{49}$ Therefore the committee proceeded on the assumption that private land ownership and the principle of compensation should be retained, and proposed a method for eliminating inflated compensation and facilitating recovery of betterment. ${ }^{50}$

45. See Barlow Report 114; Uthwatt Report 16, 123-125. As a result, by 1942 there had been only three cases in which betterment was collected. $I d$. at 124 .

46. See BarLow Report 105, 113, 239.

47. "Ownership of land involves duties to the community as well as rights in the individual owner. It may involve complete surrender of the land to the State or it may involve submission to a limitation of rights of user of the land without surrender of ownership or possession being required. There is a difference in principle between those two types of public interference with the rights of private ownership. Where property is taken over, the intention is to use those rights, and the common law of England does not recognise any right of requisitioning property by the State without liability to pay compensation to the individual for the loss of his property. The basis of compensation rests with the State to prescribe. In the second type of case, where the regulatory power of the State limits the use which an owner may make of his property, but does not deprive him of ownership, whatever rights he may lose are not taken over by the State; they are destroyed on the grounds that their existence is contrary to the national interest. In such circumstances, no claim for compensation lies at common law." UthWATt REPORT 19, 20.

48. UThWATt REPORT 22.

49. "If we were to regard the problem provided by our terms of reference as an academic exercise without regard to administrative or other consequences, immediate transfer to public ownership of all land would present the logical solution; but we have no doubt that land nationalisation is not practical as an immediate measure and we reject it on that ground alone." Uthwatt REPORT 27

50. The Uthwatt Committee proposed two complementary schemes. The first proposal provided that outside of built-up areas, development rights to land be acquired by the state at once with payment of compensation out of a fixed sum representing the value of all such development rights taken as a whole; then as permission to develop is granted by planning authorities, that the land itself be purchased by the state and leased back to the private developer. In existing built-up areas, on the other hand, the Commission felt that land should be purchased outright in areas requiring extensive redevelopment, and that to balance the cost of such purchase a periodic levy should be imposed on all increases in land values. UTHWATt REPORT 27-30. 
The Town and Country Planning Act of 1947 adopted a variant of this method. Under the Act, the nation in effect acquires at once all rights to develop land beyond its existing use and sells this right back to landowners whenever permission is granted by the local planning authority for a particular development. ${ }^{51}$ This operation is to be carried out on a unified national basis by the Central Land Board, a public corporation. ${ }^{52}$

The compensation of landowners for lost development rights is fixed in two steps. First the Central Land Board determines the development value of each separate landholding, subject to review by a quasi-judicial tribunal. ${ }^{53}$ For this purpose development value is defined as the difference on April 1, 1948 , between "unrestricted value," or market value of the land as if the Act had not been passed, and "restricted value," or market value on the assumption that no permission would be granted for any future development under the Act. ${ }^{54}$ This development value is treated as a claim of the individual landowner against the Board. Then the Board satisfies all these claims, not in full, but pro-rata out of a "global sum" of $£ 300,000,000$ set aside by the

Then in 1944 the Coalition Government in a White Paper proposed the uniform treatment of all land, with levy of a development charge amounting to $80 \%$ of development value every time permission to develop is granted, and with equally piecemeal payment of compensation for loss of existing development value whenever permission is refused. THE Control of LAND UsE 7-9 (Cmd. 6537, 1944). The 1947 Act combined features of both the Uthwatt and the 1944 proposals.

51. The term "public acquisition and resale of development rights," coined by the Uthwatt Committee, is a graphic way to describe payment of compensation and recovery of development charge under the 1947 Act. It is not, however, strictly accurate, since the Act nowhere vests these rights in the state. See 432 H.C. DEB. 976 (5th ser. 1947).

52. TCPA $\S 2,65,69$.

53. TCPA $\$ 80,61$. The procedure is as follows: (1) The individual landowner files a claim with the Board, giving information on the basis of which the assessment can be made. Claims for Depreciation of Land Values Regulations, 1948 (S.I. 1948 No. 902) §3. (2) The Board fixes a tentative development value. Id. $\$ 12(2)$. (3) The landowner may protest, setting forth his grounds for objection to the Board's figure and a proposed figure of his own. $I d . \$ 12(4)$. (4) After considering the protest, the Board makes a second determination. Id. $\$ 12(5)$. (5) If the landowner disputes this decision of the Board, he may lay the dispute before the Lands Tribunal in accordance with the Lands Tribunal Act, 1949, 12 \& 13 GEo. 6, c. 42. This Tribunal is a board of barristers and land valuers appointed by the Lord Chancellor. Id. \$2. Its decision, while final as to questions of fact, may be appealed to the High Court on questions of law. $I d$. $\$ 3(4)$.

54. TCPA $\S 61$. In assessing "restricted value" and "unrestricted value," the following rules apply:

(1) "The value of land shall, subject as hereinafter provided, be taken to be the amount which the land if sold in the open market by a willing seller might be expected to realise: Provided always that the arbitrator shall be entitled to consider all returns and assessments of capital value for taxation made or acquiesced in by the claimant."

(2) "Where the value of land is increased by reason of the use thereof or of any premises thereon in a manner which could be restrained by any court, or is contrary to law, or is detrimental to the health of the inmates of the premises or to the public health, the amount of that increase shall not be taken into account."

TCPA $\$ 62$, incorporating Acquisition of Land (Assessment of Compensation) Act, 1919, $9 \& 10$ GEo. 5, c. $57, \S 2$, Rules (2), (3) and (4). 
Act. ${ }^{55}$ The global sum represents an estimate, based on past experience, of the present worth of the value which will accrue to all land in the United Kingdom as a result of future development. ${ }^{56}$ By this correction of market values against the total development rate, inflated compensation is to be avoided. ${ }^{57}$

Development rights are sold back piecemeal to landowners by levying a development charge whenever permission to develop land is granted by the planning authority. ${ }^{58}$ Theoretically, the development charge represents not only betterment from the shifting effect of public regulation, but in addition the increase in value brought about by any other factors of community growth which make possible the change to a more profitable use. It is assessed and collected by the Control Land Board. ${ }^{59}$ The general standard

55. TCPA § 58. Division of the "global sum" among landowners will be made "by reference to the development values of their interests respectively" and/or "by reference to ... other circumstances affecting those interests" in a manner to be determined by a scheme issued by the Treasury with the approval of both Houses of Parliament. Id. $\S 58(4)$, (6). Landowners claims have all been made, but assessment is not yet completed. Issuance of the Treasury scheme is scheduled for 1953. 157 Ecowonnst 395 (1949). Payment will be made in Government stock. TCPA \$ 65.

56. The estimate is an exceedingly rough one. In making it, the draftsmen of the Act accepted the Uthwatt Committee's determination that the average pre-war rate of development of undeveloped land outside towns was 45,000 acres per annum, the average annual increment in value arising from development $£ 200$ per acre, and the resulting annual figure $£ 9,000,000$. They used the capitalization rate of "sixteen years purchase," or $6.25 \%$, conventional in British real estate valuation, to reach a figure of $£ 144,000,000$ as the total present worth of this annual increment, which they "rounded off" to $£ 150,000,000$. Then they simply set the capital sum representing the value of development prospects in built-up areas at the same figure, to reach a total of $£ 300,000,000$. See 432 H.C. DEB. 980 (5th ser. 1947).

57. The degree to which landowners' claims will in fact be deflated is uncertain until the payment scheme is prepared. Though all claims had been received by June 1949, opinions as to the expected total of the individual assessments as compared with the global sum vary widely. See Monson, Development and Practice of British Planning Law, 44 ILL. L. Rev. 779, 790 (1950): "Published comments so far indicate that . . . claimants will feel more or less aggrieved, since estimates of what the Fund should have been run to over . . . three times that actual amount provided in the Act." But see 157 Economist 395 (1949): "[It is likely that] compensation will be paid on a more adequate scale than was originally expected." Recently the Royal Institute of Chartered Surveyors has suggested that in 1947 tight building controls prevented as great an inflation of compensation claims as was expected by the framers of the Act. R.I.C.S. Memo. on The Town and Country Planning Act, 1947 \$282, reprinted in [1950] J. OF PLANNING LAw 717.

58. TCPA $\$ 69$.

59. TCPA $\$ 70$. The Act provides for no judicial or other review of development charges. However, the Board must issue regulations, approved by Parliament, setting forth the particular principles it will follow in applying the general standard prescribed in the Act. Id. $\S 70(3)$. Failure of the Board to follow these principles may give an aggrieved party an opportunity to obtain judicial review of Board action. In the opinion of one writer, "If the Board fail to comply with the Regulation in any particular case, their determination should be held to be a nullity. But the failure to comply with the Regulations could only be established, if either it was apparent on the face of determination-a most unlikely eventor the determination was so unreasonable that the Court would infer that the wrong prin- 
for fixing the development charge is the excess of the value of the land with consent for the development in question over its value if permission were to be refused..$^{60}$ However, the Board may vary the charge for different types of development, or for development carried out at different periods. ${ }^{61}$

The Act further provides that when a local authority acquires land by compulsory purchase, it is to pay the landowner only the existing use value of the land.62 This rule is designed to place the landowner whose land is publicly acquired in the same position as one who sells to a private developer - since the private developer must pay the development value to the government as development charge, his seller will supposedly be unable to get more than the existing use value from him. In each case the seller looks to the global sum rather than to the local authority or the private developer to recompense him for the development value of his land.

The assessment of development charges touches the core of the most serious new problem raised by the Act: can the shifting of land values be equalized without destroying the incentive to private land development? On the one hand, the shifting effect of land use regulation on land values will disappear only if land is bought and sold at its value for its existing use. If expectations of more profitable future use creep back into land prices, the fulfilment or non-fulfilment of these expectations will again cause private gains and losses. To keep these expectations out of land prices, the development charge must absorb the entire value added to the land when change to a more profitable use is permitted. On the other hand, if the price of land plus the development charge is too high, it will cut down the profit margin which

ciples must have been applied. As a practical matter then the Regulations do not give much scope for judicial control of the Board's assessment." White, Private Rights and Ministerial Action, [1948] J. of Planning Law 477, 480.

60. TCPA $\$ 70(2)$. The Act does not define "value" as used in $\S 70$. Regulations implementing the section use only the term "value, measured by the normal processes of valuation." Town and Country Planning (Development Charge) Regs., Schedule \$ 2. (S.I. 1948 No. 1189). However, the Central Land Board interprets this language to mean market value, $i . e .$, the price that would be paid to a willing buyer by a willing seller. CENTRAL LAND BoARd Practice Notes (FIRST SERIES) \$\$ 35-48 (1949).

61. TCPA $\S 70(3)$. Apparently the purpose of this provision is to allow the Board to reduce the percentage of development value absorbed by the development charge in particular cases in order to encourage particular types of development. See 432 H.C. DEB. 983 (5th ser. 1947). In its first regulations, however, the Board has renounced the use of this power. See note 65 infra.

62. TCPA $\$ 51(1)$, (2), incorporating The Acquisition of Land (Assessment of Compensation) Act, 1919, 9 \& 10 GEo. 5 , c. 57. When land is acquired by compulsory purchase, however, compensation does not include land value attributable to a use which is illegal or detrimental to public health. Ibid. For the importance of this limitation in public acquisition of slum areas, see Note, Condemnation of Slum Land-Illegal Use as a Factor Reducing Valuation, 14 U. OF CHr. L. REv. 232 (1947).

When a local authority, rather than acquiring the land, orders the owner to terminate an existing use, see page 118 and note 32 supra, the compensation it must pay for the resulting depreciation in the value of the land is measured by the value for the existing use, henceforth forbidden, minus the value for the new permitted use. TCPA $\$ 27$. 
induces a shift to new uses. The result may be to jeopardize private land development. ${ }^{63}$

The framers of the Act believed that this problem was not insoluble. They argued that if existing use value plus development charge were equal to market value for the new use, trading at existing use value would be assured. And they felt that the market would, by its normal operation, fix the value for the new use at a level allowing the developer sufficient profit to induce him to proceed; otherwise demand at this price would disappear, and the market price would fall. ${ }^{64}$

However, in the first two years of the Act's operation the Central Land Board has been unable to make the land market conform to this neat theory. The Board has concentrated on ensuring that land is bought and sold at existing use value. To this end it has tried to fix development charges at $100 \%$ of estimated development value, with no variation to encourage or discourage particular types of development. ${ }^{65}$ Nevertheless, while private development has apparently not been seriously retarded, ${ }^{66}$ land eligible for development permission has continued to change hands at prices well above existing use value. ${ }^{67}$

The explanation of this unexpected result may lie in a factor neglected by the framers of the Act: the incentive not for the developer, but for the owner who sells land to him. Unless the seller can get more than the existing use value from the developer, he has no reason to sell instead of keeping the land

63. See 451 H.C. DEB. 296-8 (5th ser. 1948); 154 Economist 1005 (1948); 155 ECONOMIST $489,614-15$ (1948).

An example may help to point up the effect of excessive development charges on private incentive. Suppose that the market value of a piece of land on the periphery of a city is $£ 50$ for its present agricultural use, but that its market value for immediate use as a building lot is $£ 350$. This market value as a building lot presumably indicates that a builder can buy it at this price and still make sufficient profit from developing and then selling or renting the property to induce him to go ahead. Under these assumptions, a development charge of $£ 300$, plus the existing use value of $£ 50$, would result in a total price of $£ 350$, which would leave the builder's profit intact. However, a development charge of $£ 325$ would bring the cost to the builder to $£ 375$. This increase in the cost of the land might, if construction costs and final rental or sales price of the property remained constant, squeeze out the builder's profit entirely.

64. See the statement of Edward Silkin, the Minister of Town and Country Planning, in 451 H.C. DEB. 303-4 (5th ser. 1948). And see 154 EcononIst 1005 (1948).

Assessment of development charges on a "market value" standard appears in fact to be leaving the developer a fairly large margin of profit. One observer reports that development charges, though purporting to be $100 \%$ of the development value by a market value standard, amount to only a third of development value computed by capitalizing net income from the new use and subtracting from it existing use value. BRADY, CRISIS IN BrITAIN 425-6 (1950).

65. Town and Country Planning (Development Charge) Regulations, 1948 (S.I. 1948 No. 1189).

66. See 157 EconoMIst 1173 (1949).

67. Report of the Central Land Board for the Periop to 31 March, 1949, 11-12; Report of the Central Land Board for the Period to 31 Marce, 1950, 9-10. See also 155 ECONOMIST 489, 614 (1948); 157 EcoNomist 395, 1173 (1949). 
at its existing use. The fact that sales have taken place at prices above existing use value seems to indicate that present development charges are low enough to permit the developer to offer a measure of profit to his seller. The profit margin left to the developer under the market value method of assessing development charges is in fact split between the developer and the seller. ${ }^{65}$ To prevent payment of more than the existing use value by the developer, the development charge would probably have to be high enough to absorb the developer's entire profit. Such a development charge would bring private development to a standstill. ${ }^{69}$

It may therefore be impossible to eliminate shifting value entirely by means of the development charge. But the essential purpose of the Act may nevertheless be fulfilled. The amount by which land prices exceed existing use value may be large enough to provide incentive for sales to developers, and at the same time small enough to keep shifting value from causing appreciable hardship to landowners. Only further experience will show whether the Central Land Board can assess development charges precisely enough to preserve the incentive to private development and at the same time hold shifting value at an innocuous level..$^{70}$

\section{Planning Goals}

\section{American Prospects}

Reorganization of the urban pattern as sweeping as that contemplated under the British Town and Country Planning Act of 1947 has not yet become a goal of practical community action in the United States. ${ }^{71}$ In this country operating plans and land use controls have usually followed the general pattern produced by unregulated urban growth, and have attempted

68. See R.I.C.S. Memorandum on the Town and Country Planning Act, $1947 \$ 279$, reprinted in [1950] J. of PlannIng LAw 716; The Shortcomings of the Tozen and Country Planning Act, 1947, 93 Sol. J. 669-70 (1949); 155 Econouist 614 (1948).

69. The Board has not experimented with raising development charges. However, it has occasionally used its power of compulsory purchase to buy at existing use value from a recalcitrant sellor and resell at the same price to a would-be buyer. REPORT, 1950, op. cit. supra note 67.

70. The Royal Institute of Chartered Surveyors recently advised that the Board abandon the attempt to hold land trading exactly to existing use value, and frankly levy development charges of less than development value in order to preserve incentive. R.I.C.S. Memorandum on the Act of $1947 \$ \$ 328-337$, reprinted in J. OF PLANNING LAw 721 (1950).

71. Even the long-range plans of American planning commissions, not yet implemented by land use control measures, propose a much less sweeping change from the status quo than do their British counterparts. Compare, e.g., ChICAgo PLAN Commrssion, Master Plan of Residential Land Use in Chicago (1943), with Abercrombie, The Greater London Plan 1944 (1945). And see City Planning and Zoning Commission, City Plan of Salt Lake City, Utah (1943); Segoe, Planning Metropolitan Cincinatti; Basic Policies, and Dill, The Cincinatti Melropolitan Master Plan, in AMERICAN Society of PlanNing Officials, Planning 1947, 56-72. 
to alleviate such problems as mixed land use, blight, and extreme overcrowding by relatively minor changes in that pattern..$^{2}$

However, the conception of a more desirable urban pattern and the general program for its development which form the foundation of British planning are widely shared by American city planners. These planners generally recognize the need for reorganization of central residential and commercial areas at a lower population density, in more nearly self-contained neighborhoods, with much more open space. ${ }^{73}$ They regard as an essential corollary of central reorganization the control of city expansion at the periphery to prevent new congestion and to preserve open areas"greenbelts or greenwedges" - between residential districts. ${ }^{74}$ A number of them also feel that clusters of self-contained "satellite" towns are the only feasible long-term solution to the problem of metropolitan congestion. ${ }^{75}$

Not until these aspirations of American planners gain enough public support to be incorporated into community policy will Americans face the same problems which the British faced in the Town and Country Planning Act. When that day comes, Americans will have to decide for themselves a number of questions: whether their techniques for determining community design and controlling land use are adequate; what, if anything, is to be done about the problem of shifting land values; how applicable is the British treatment of this problem to American conditions; and what alternative solutions are available.

\section{Determination of Community Design and Control of Land Use}

Community design is determined at the municipal level in the United States in approximately the same way as under the British Town and Country Planning Act. Forty-five of the states have enacted enabling legislation by which municipalities may establish planning commissions and adopt master plans. ${ }^{76}$ These plans, including the same range of subjects as

72. See page 133 and notes 110 and 111 infra. Furthermore, presently contemplated urban redevelopment projects will reduce population density in former slum areas somewhat, but will seldom alter their relatively dense residential use in any fundamental sense. See Brown, Urban Redevelopment, 29 B.U.L.Rev. 318, 347-367 (1949).

73. See, e.g., National Resources Committee, Our Citres 84-85 (1937); SaArinen, The City, Its Growth, Decay and Future 200-266 (1943); Sanders \& Rabuck, New City PatTerns 153-162 (1946).

74. There seems to be considerable agreement among planners that the outward growth of cities should be interrupted by permanently reserved open areas. There is, however, lively controversy over whether this open space should take the form of a circular greenbelt dividing the central city from satellite communities, or of wedges of open space dividing areas of residential development running radially from the center. See, e.g., the various points of view presented in The New York Region-A Case Study in the Limitation of Growth by Sprawl, in American Society of Planning Officials, Planning 1948, 9-26.

75. Id. at 12-15. And see Windels, At the Crossroads (New York Regional Plan Association, 1948); SANDers \& Rabuck, New City Patterns 162-170 (1946).

76. International City Managers Association, local Planning Administration 24 (2d ed. 1948) (hereinafter cited as Local Planning Administratron) lists forty- 
British development plans, ${ }^{77}$ are normally based on a physical, ecconomic, and social survey of the community by the planning commission. ${ }^{78}$ They may be adopted by the municipal legislative body, as under the British Act, or by a planning commission created by the legislative body. ${ }^{79}$

Few, if any, municipal governments, however, exercise control over the entire area within which substantial decentralization of the urban pattern must be carried out. ${ }^{80}$ This problem could best be solved, in a manner analogous to that adopted in Great Britain, by the transfer of municipal powers of planning and control of land use to authorities created by state statute or inter-municipal agreement, each with jurisdiction over an entire metropolitan area. ${ }^{81}$ A number of states have enabling legislation for the creation of such planning bodies, ${ }^{82}$ but these bodies are granted only limited advisory functions $^{83}$ and never cut across state lines. Joint authorities with comprehensive powers within their field of action are widely employed for other

four states as of November, 1947. Since then another state has adopted planning enabling legislation. N. MEx. Star. ANN. \$\$ 14-214-14-233 (Supp. 1949).

77. Compare Local Planning Administration 51 and Dep't of Cominerce, A Standard City Planning Enabling Act \$ 6 (1928) with TCPA \$ 5, note 21 supra. And see Bassetr, Williatrs, Bettuan \& Whitten, Model Planning Laws (1935) passim.

78. See Local Planning Administration 59-67.

79. Id. at 30 .

80. The 1940 census reveals 140 metropolitan districts in the United States, ranging in population from 53,000 to $10,500,000$. No one of these districts was organized as a single city. Instead, in the 140 districts there were 172 central cities, 1697 suburban municipalities, 302 counties, and a huge number of special districts and authorities. Jones, Government in the Future City, 242 AnNals 79 (1945).

Presumably urban decentralization, whether or not carried out by the creation of new satellite communities, will involve shifting of population and industry within the entire commuting circle of each central city. It can therefore be directed only by a governmental unit which can plan for this area as a whole.

81. For a full discussion of the shortcomings of other methods for the exercise of planning powers in areas of efficient size, and of the advantages of the metropolitan regional authority, see McDougaL \& HABER, op. cit. supra note 5, at 751-766.

82. Fifteen states had such legislation as of 1947. Local Planning Administration 24. In some states the Governor, on application of the municipalities concerned, defines the area and appoints the planning commission. E.g., CAL. GEN. LAws, Act 5211c, \& 30 (Deering 1949 Supp.); AlA. Code title 37, § 809 (1940); Ky. REv. STaT. \$147.130 (1948). In others, joint commissions are formed solely by agreement between municipalities. E.g., Conn. Stat. $\$ 863$ (1949 rev.); Omo Gen. Code $\$ 4366-13$ (Page 1937); N.Y. Gen. Mun. Law, Art. 12B, $\$ 239$ b (Baldwin 1938).

83. The most far-reaching statute, that of California, provides that county and city master plans "shall be coordinated" so as to fit into master plans adopted by the regional planning commission. However, local legislative bodies are bound only to adopt such parts of the master plan "as may practically be applied to the development of the city or county for a reasonable period of time next ensuing." CAL. GEN. LAws, Act 5211c, $\$ 48,70$ (Deering 1949 Supp.). In the other states plans prepared by a regional planning commission are without effect until adopted by the component municipalities, which are free to adopt their own plans instead. E.g., AlA. CoDE, title 37, $\$ 813,814$ (1940); Ill. Stat. ANn., c. 34, $\$ 152 d$ (Smith-Hurd 1936); N.Y. Gen. Mun. Law, Art 12B, \$239-d (Baldwin 1938). 
municipal purposes, ${ }^{84}$ but their potentialities for land use planning have not been exploited.

Coordination of municipal or metropolitan land use plans on a regional or national basis has not been attempted in the United States. ${ }^{85}$ However, such coordination will become necessary, as it did in Great Britain, if urban reorganization entails substantial redistribution of population or industry. ${ }^{\mathrm{so}}$ The size, federal structure, and decentralized political system of the United States militate against national supervision of local planning. ${ }^{\$ 7}$ Regional authorities of the type developed to solve power, irrigation, drainage, and soil conservation problems for an entire river basin would be coordinating agencies more suited to American needs. ${ }^{s s}$ States might, by compact, delegate supervision of municipal planning upward to such regional authorities in the same manner as they now delegate powers of planning and land use control downward to the municipalities. ${ }^{83}$

Once community design is determined, regulation of private land use in the United States is carried out not by administrative application of the provisions of the municipal master plan, as in Great Britain, but by separate detailed municipal ordinances. Such ordinances are of two principal types, zoning ordinances and subdivision regulations.

84. E.g., public works development and maintenance, sewage disposal, water supply. See Fox \& Fox, Municipal Government and Special Purpose Authorities, 207 ANNals 176 (1940); McDougal \& HABER, op. cit. supra note 5, at 764.

85. In 1937, however, the Urbanism Committee of the National Resources Committee recommended that Congress give a national agency authority to "develop, in collaboration with State planning boards, a better balanced and more socially desirable national industrial pattern, possibly a national zoning plan for industry. ..." National Resources Commirtes, OUR Cities 79 (1937). This recommendation was never carried out.

86. The British discovered that municipal and metropolitan governmental units would not, without national supervision, plan to reduce the population or industrial concentration on which the local tax base depends, and that a mosaic of independent local plans would not produce a satisfactory distribution of population or industry from a regional or national point of view. See BARLow Report 106; Uthwatr Report 9. There is little reason to suppose that experience in the United States would be different.

87. The difference in scale and administrative complexity of any system of national coordination of local planning in thé United States as cómpared with such a system in Great Britain is obvious. It would, moreover, be difficult to find constitutional warrant for supervision by the federal government of state land use control. And the most powerful obstacle to such federal action would probably be the traditional American political preference for governmental decentralization.

Though direct federal review of regional or local plans would not be feasible, the federal government might, in accordance with established practice, stimulate, support, and guide regional planning activities by means of conditional grants-in-aid to participating states. Such federal aid may indeed be essential to the establishment of adequate regional planning machinery.

88. See Directive Committee on Regional Planning (Yale University), The Case for Regional Planning with Special Reference to New England (1947). For an analysis of the legal and administrative problems of the regional water resources planning authority, see Comment, 56 Y ALE L.J. 276 (1947).

89. See $i d$. at $293-302$. 
Zoning ordinances divide the community into different areas, in each of which uniform restrictions are applied to the type of land use, bulk and height of buildings, lot coverage, and population density. ${ }^{90}$ Zoning may thus be used to improve the general arrangement of commercial, industrial, and residential areas, ${ }^{91}$ and to limit and gradually reduce congestion. ${ }^{92}$ Moreover, within each neighborhood unit, it may be used to bring commercial, residential and other facilities into proper relation. ${ }^{93}$ Zoning is at present seldom used to regulate the peripheral expansion of cities in order to bring about a desirable relation between residential development and open space reserved for agricultural use. However, if this particular reform of the urban pattern is desired, it could be effected by the recently developed rural zoning ${ }^{94}$ when carried out jointly by urban and semi-rural municipalities. ${ }^{95}$

Zoning ordinances are usually administered through the granting of building and occupancy permits. ${ }^{96}$ In contrast to British "development permission," however, such permits cannot be refused if the building or use complies with the express restrictions of the ordinance. And relaxation of these restrictions in particular cases is usually possible through a board of zoning appeals which may grant "variances" according to standards provided in the zoning ordinance. ${ }^{97}$

Zoning does not force immediate cessation of uses of land which were in existence before the ordinance. ${ }^{98}$ However, some recent zoning ordinances provide that a non-conforming use must cease after a period sufficient for the

90. See, generally, Bassetr, Zoning (1936); Local Planning Administration 218-247. Zoning began in the United States in the late 19 th century as a means of regulating nuisance-like land uses. The first zoning ordinance regulating use, height, and area of buildings was adopted by New York City in 1916. Since that time zoning has gradually developed into an instrument which may be used to effectuate a community plan. For a concise summary of the history of zoning, see Walker. The Planning Function in Urban Governament 50-89 (1950).

91. See Local Planning Administration 227-9.

92. Id, at 231-233.

93. See, e.g., Adams, Design of Residentral AReas 160-167 (1934); Local Planning AdMinistration 204-206.

94. See Warp, The Legal Status of Rural Zoning, 36 ILL. L. Rev. 153 (1941). In 1947 nineteen state enabling acts permitted rural or "county" zoning. Local PLANNING ADMINISTRATION 24.

95. The Los Angeles Zoning Ordinance of 1946, which applies to large areas of the San Fernando Valley as well as to the city itself, has two types of agricultural districts and one "suburban residential" district in addition to the usual urban land use classes. Christensen, Zoning and Planning, MUNicipalities AND the LAw IN ACTION 285, 293-4 (Rhyne ed. 1947).

96. Local Planning Administration 242-3.

97. Id. at 243-46. Zoning restrictions may also be relaxed in particular cases by judicial determination that an ordinance, though valid in general, is unreasonable as applied to particular property. E.g., Taylor v. Village of Glencoe, 372 Ill. 507, 25 N.E.2d 62 (1940). And municipal legislative bodies often amend zoning ordinances piecemeal in response to the wishes of particular property owners. See Note, 9 U. OF CHI. L. REv. 477, 490-91 (1942).

98. See id. at 484 . 
owner to amortize his investment. ${ }^{99}$ The British practice of ordering cessation of such use and compensating the owner for his loss has never been adopted in the United States.

Subdivision regulations are a relatively new and powerful weapon for improving the design of new residential areas. ${ }^{100}$ They require that the arrangement and width of streets, the dimensions of blocks and lots, the provision of open space for parks and public building sites, and in some cases population density and building walls, comply with the master plan and with general standards established by the municipal planning commission. ${ }^{101}$ These requirements must be met before land may be subdivided into building lots. ${ }^{102}$ Subdivision regulations are usually administered directly by the planning commission exercising powers delegated to it by the municipal legislative body. ${ }^{103}$

Where regulation of private land use proves inadequate-most often in areas requiring intensive replanning and redevelopment-public acquisition by purchase or condemnation is employed in the United States as well as in Great Britain. At present this technique of land use control is applied chiefly to slum and blighted areas and public housing sites under the impetus of federal financial aid. ${ }^{104}$ However, subject to occasional resurrection by the

99. E.g., MAss. AcTs 1941 c. $373, \S 8$ (1941), as amended Mass. Acts c. $214, \S 1$ (1948) (nonconforming use to terminate either by 1961 or thirty-seven years after passage of a zoning amendment rendering a previously conforming use nonconforming, whichever is later); Los Angeles Zoning Ordinance of March 7, 1946, cited in MuNIcrPALITIES AND THE LAw IN ACrion 285, 293 (Rhyne ed. 1947) (termination twenty, thirty, or forty years after the construction date of the nonconforming building, depending on the type of building; provision to go into effect twenty years from date of enactment). For a discussion of such provisions, see Note, 9 U. of CHr. L. REv. 477, 480-6 (1942).

100. "It has been said . . . that subdivision was better controlled early in American History than they have been ever since. Such control as existed broke down, however, in the era of unrestricted land speculation, and regulation has been revived only within the last two or three decades." Walker, The Planning Function in Urban Governarent 90 (1950). By 1944 all but four states-Rhode Island, Vermont, Florida, and Mississippiprovided for some form of subdivision regulation. CoMparatrve ANalysis of THE PRINCIpal Provisions of State Subdivision Control Laws (Office of General Counsel, Federal Housing Agency, 1945) (hereinafter cited as Cosiparative ANalysis). On subdivision regulation generally, see Lautner, Subdivision Regulation (1941); Local Planning AdMINTSTRATION 248-267.

101. Ibid. Subdivision regulation can usually be exercised by the city over a several mile radius outside the city limits. For a tabulation of the aspects of subdivision regulated by municipalities under various state enabling statutes, see CoMPARATIVE ANALYSIS.

102. Unless a subdivision is approved, the privilege of public record of the subdivision plat is usually withheld. The difficulty of selling the lots in the subdivision by metes and bounds renders this sanction effective. See Local Plannung Administration 253.

103. Id. at 266-7. For provisions in state enabling statutes relating to the administration of subdivision controls, see CoMparative ANAL ysis.

104. The most recent federal legislation aiding local slum clearance projects is the Housing Act of 1949, 1 U.S. Code Cong. Serv. 408 (1949). See Comment, The Housing Act of 1949, A Federal Program for Public Housing and Slum Clearance, 44 ILL. L. REv. 685 
courts of the "public use" limitation on the power of eminent domain, ${ }^{105}$ public ownership might be used for other aspects of urban reorganization as well. ${ }^{106}$

Existing American methods of land use control are thus technically adequate, with some extensions and refinements, to secure compliance with the land use pattern which is the goal of urban reorganization. Their relative rigidity and narrower scope in comparison with British counterparts need not seriously reduce their effectiveness for this purpose. ${ }^{107}$ However, since the pattern which is the goal of urban reorganization represents a substantial departure from the pattern created by the market, the techniques may never be used to enforce such reorganization unless a successful solution can be found to the problem of shifting land values.

\section{The Land Value Problem; American Experience}

The problem of shifting land values has remained in the background under the American system of regulation of private land use. Zoning and subdivision controls are imposed without compensating landowners for losses in the value of their land resulting from restriction of land use. These controls have won judicial approval as an exercise of the "police power" of the states to restrict the use of property without compensation where necessary for the general welfare. ${ }^{108}$ Since compensation is not granted, the recovery of betterment is unnecessary. As a result, in the United States the effect of regulation on land values has not demanded explicit consideration.

At the same time, regulatory measures actually adopted by American

(1949). On the redevelopment of slum and blighted areas generally, see Brown, Urban Redevelopment, 29 B.U.L. REv. 318 (1949); Comment, 54 YALE L.J. 116 (1945).

105. See Comment, The Public Use Limitation on Eminent Domain; An Advance Reguiem, 5 S YALE L.J. 599 (1949).

106. See pages 137-8 infra.

107. The necessity for formal amendment of a zoning or subdivision ordinance every time practice reveals even minor defects in its detailed provisions may cause difficulties not present when an administrative agency, as in Great Britain, applies the more general provisions of a development plan. This difficulty, however, can probably be minimized by careful and informed drafting, combined with frequent and full review of zoning and subdivision ordinances.

British development permission apparently allows local planning authorities to regulate details of construction and design which are not touched by American zoning classifications or subdivision standards. See Light, Aesthetics in Zoning, 14 MrNo. L. Rev. 109 (1930); Walker, The Planning Function in Urban Govermment 93-4 (1950). However, regulation of street and lot layout, population density, amount of open space, and use would cover all the essential aspects of urban reorganization.

108. E.g., Soon Hing v. Crowley, 113 U.S. 703 (1885) ("nuisance" zoning; exclusion of a Chinese laundry from a residential district); Hadacheck v. Sebastian, 239 U.S. 394 (1915) (city-wide use zoning applied to a use without "nuisance" characteristics); Village of Euclid v. Ambler Realty Co., 272 U.S. 365 (1926) (comprehensive zoning; regulation of height, area, use); Mansfield \& Swett, Inc. v. Town of West Orange, 120 N.J.L. 145, 198 Atl. 225 (Sup. Ct. 1938) (subdivision control). 
municipalities have shifted land values to only a limited extent. ${ }^{103}$ Zoning laws usually lay out residential, commercial, industrial, and sometimes agricultural zones according to the general pattern which was expected to develop without regulation. ${ }^{110}$ Their effect is merely to protect each zone from the scattered intrusion of incompatible land uses. Subdivision laws usually allow the subdivision of land, subject to easily fulfilled conditions, in all areas where there has been any prospect of residential development. ${ }^{111}$ Therefore zoning and subdivision regulation, as carried out in this country, have shifted land values in isolated cases only. ${ }^{112}$

The adherence of zoning and subdivision laws to the general pattern of land use already expected by landowners, and therefore reflected in land values, is due partly to the fact that publicly supported planning goals have not in the past included wholesale revision of this pattern. But the political strength of real estate investors holding land in the expectation of more profitable future use has also been a serious obstacle to the passage of reg-

109. Present American land use regulation has had substantial effect on land values in other ways, however. See note 38 supra.

110. "But, it may be asked, haven't we been using zoning to control land use and population density for twenty-five years? Obviously, no. . . . In very few instances has zoning been effective in decreasing population density, or in revising a land use pattern that needed revision. It has kept good areas from going bad, and prevented bad ones from getting worse. But it has frozen existing conditions, be they orderly or disorderly, logical or illogical." Howard, Land Use and Population Density Plan as a Basis for Zoning, AMrerican Society of Planning Officials, National Conference on Planning 280, 283 (1941). "The cry of most planners is that they cannot predict what the future of the community is going to be, and that the zoning and planning job does not include making blueprints for a new society. They say the job is a strictly technical one, specifically to preserve existing values wherever they exist, and to provide for a flexible enough ordinance so that the community may grow in a 'normal' fashion." Feiss, Zoning as a Positive Insirument of Planning, American Society of Planning Offictals, supra at 277. And see Crane, Progress in the Science of Zoning, 155 (II) ANNals 194, 195 (1931). For a good example of the correspondence between a recent zoning ordinance and the existing land use pattern, see City Planning and Zoning Cosmitree City Plan, Salt Lake City, Utar 26-34 and maps (1943).

111. Subdivision controls have been used to improve the internal layout of subdivisions, but seldom to modify the direction of urban expansion. A number of states have sought to check the overall rate of subdivision, by allowing municipalities to require that the private subdivider install satisfactory water and sewage facilities at his own expense before he can obtain approval of the subdivision. Only a few states, however, have undertaken to prohibit subdivision entirely in particular cases by requiring the subdivider to show that the public convenience and necessity would be served by the new subdivision. CoMparatrve Analysis. For a sceptical view of the efficacy of such provisions, see Local Planning ADMINISTRATION 264-5.

112. E.g., in an area where the expected use is predominantly residential, only a few strategically located lots, such as those at heavy traffic intersections, have any prospect of profitable commercial use. Only these lots lose value as a result of a zoning law classifying the area as residential. And the increase in value of land in other areas zoned for commercial use, arising from the elimination of these few commercial sites, will be negligible.

Such regulation, however, may increase the value of the land in, for example, the residential zone for its existing residential use by eliminating the shops and gas stations which 
ulations which would defeat these expectations. ${ }^{113}$ The zoning in most American municipalities of more land for profitable commercial and industrial use than will be required in several generations of normal city growth is due largely to the pressure of these interests. ${ }^{114}$ This American

would make the neighborhood less desirable from the home owner's point of view. This increase in land value for an existing use resulting from the elimination of neighboring incompatible uses has been the most prominent effect of American land use regulation. See Fisher, Economic Aspects of Zoning, Blighted Areas, and Rehabilitation Laws, 32 Ar. Econ. Rev. 331, 333-4 (1942); Monro, A Danger Spot in the Zoning Movement, 155 (II) ANnals 202, 203 (1931); Schmutz, Economic Effects of Zoning, 155 (II) ANNALs 172, 173 (1931).

113. "One of the principal reasons for the wide public acceptance of zoning can be found in the fact that real estate agents and promoters throughout the country got behind the movement. They saw in it an opportunity to boom the business. With a city entirely zoned, they could assure purchasers of residential property that their neighborhood would never be encroached upon by business, while on the other hand, zoning would give business property a touch of monopoly value. . . . Whenever a question of re-zoning comes up the issue is not usually approached from the standpoint of what the city needs but of what private owners desire and what their immediate neighbors feel disinclined to let them have." Monro, supra note 112, at 203-4. See also Walker, The Planning Function in Urban GovernMENT 23 (1950); Tugwell, The Real Estate Dilemma, 2 Pú. ADMrn. REv. 27, 30-31, 34-5 (1942). For a real estate man's point of view, see Leimert, Can Zoning be Made More Practical? 7 URBAN LAND 1 (January 1948).

114. Such overzoning has been almost universal in the United States. In an extreme example, if New York City were to be built up to the full density permitted under the zoning ordinance in effect in 1934, the capacity of residential districts would be approximately 77 million people, and the commercial district would provide space for a working population of 344 million. Ackerman, Population Expectations, Zoning, Appraisal and Debt, 49 AM. CITy 49, 50 (October 1934). For figures on other cities, see Shatts, The Relation of Zoning to Land Values, in Walker, URBan Blight and Sluns 162 (1938); Note, 9 U. of CHI. L. Rev. 477, 488-9 n. 68, 70 (1942). Even recent revisions of zoning ordinances to eliminate overzoning have sometimes stopped short of attaining their purpose. See, e.g., Redevelopment of Residential Areas in Hartford, Connecticut 3-4 (Report of the Commission on the city plan to the common council of Hartford, 1945). Overzoning may result partly from misapprehension of the rate of urban growth, but its chief purpose has been to overcome the opposition of real estate interests to zoning restrictions. See Fisher, supra note 112, at 333-4; Walker, The Planning Function in URban Governaient $23(1941)$.

Overzoning is both a cause and an effect of overly optimistic expectations as to future land use. Overzoning comes about because local legislative bodies are unwilling to defeat the expectations of land-owners holding land which they think is destined for a much more profitable future use. At the same time, once land is zoned for an intensive use, buyers and sellers of land are even more likely to set prices on the assumption that such use will be possible immediately, however unrealistic this assumption may be. Overzoning thus inflates the market value of this land. See Fisher, supra note 112, at 334; Culver, A Realtor's View of Zoning, Present and Future, 155 (II) Annals 207 (1931). This rise in value may make it unprofitable for owners to devote this land to a less intensive use, such as low density residential building. They are therefore encouraged to neglect existing buildings and establish miscellaneous "temporary" uses to tide them over. And when the expected intensive use fails to materialize, the delapidated old buildings and "temporary" uses remain and the area becomes "blighted." Thus overzoning has been a principal contributing factor to urban blight in American cities. See Fisher, supra note 112, at 334; Shatts, supra, at 167-71; Black, Planning for the Siall Amerrcan City 40 (1944). 
over-zoning is exactly analogous to the over-zoning practiced in local planning schemes in Great Britain before 1947 in order to avoid compensation liability. ${ }^{115}$ Thus the phenomenon of shifting land values, though not expressly recognized in American land use regulation, has operated below the surface to shape the substance of zoning and subdivision laws.

\section{The Land Value Problem; American Alternatives}

The problem of shifting land values will be met head on if American communities ever attempt a reorganization of their physical pattern as farreaching as that now being carried out in Great Britain and advocated by many American city planning technicians. Preservation of open space between new residential areas will require restriction to agricultural use of large areas of land whose value reflects the prospect of residential building. ${ }^{116}$ Dispersion of commercial centers and reduction of central congestion will require restriction to residential use of much land whose value is based on expected high density commercial use. ${ }^{117}$

Regulation without compensation. Continued regulation of private land use without compensation will face two obstacles when employed for basic urban reorganization: courts may hold that the intensified effect of such regulation on land values places it beyond the limits of the police power; and the political strength of large groups of financially affected landowners may prevent the adoption or warp the content of such regulation.

The judicial hurdle could probably be cleared. Redirection of zoning and subdivision controls to bring about a basic reorganization of the urban pattern would bring no increase in the number of aspects of land use regulated. ${ }^{118}$ It would only give familiar types of regulation a greater impact on land values. Courts have consistently upheld zoning laws, in spite of their drastic reduction of land values in individual cases, when zoning has met a certain qualitative standard. ${ }^{119}$ This standard is most commonly formulated

115. See page 121 and note 46 supra.

116. Except where city growth is blocked by topographic factors, most cities are surrounded by a fairly continuous belt of open land being held in the expectation of future residential building. See U.S. National Resources Planning Board, Public Land Acquisition in a National Land Use Program: Urban Lands 2-3 (1940); 2 Regional Survey of New York and ITs Environs 139-40 (1929); WeIMer \& Hoyt, Principles OF URBAN REAL EsTATE 58-70 (1939).

117. On the land value pattern surrounding central commercial districts, see WAIKER, URban Blight AND SiUMS 7-11 (1938).

118. See note 107 supra.

119. E.g., Zahn v. Board of Public Works, 195 Cal. 497, 234 Pac. 388, aff'd, 274 U.S. 325 (1927) (restriction to residential use reduced value of appellant's property $60 \%$ ); Village of Euclid v. Ambler Realty Co., 272 U.S. 365 (1926) (ordinance reduced value of appellant's property from $\$ 10,000$ per acre to $\$ 2500$ per acre); Hadacheck v. Sebastian, 239 U.S. 394 (1915) (ordinance reduced value of appellant's property from $\$ 800,000$ to $\$ 60,000$ ). And see Devany v. Board of Zoning Appeals, 132 Conn. 537, 45 A.2d 828 (1946); Leventhal v. Dist. of Col., 100 F.2d 94 (D.C. Cir. 1939). A few courts still hold value reduction to be a factor, though not necessarily the decisive one, in determining the validity of a zoning 
as "a reasonable and substantial relation to public health, safety, convenience and welfare." 120 It has at times been applied to forbid an arrangement of zones which differs radically from the existing land use pattern. ${ }^{121}$ But it seems probable that the courts will find a sufficiently close relationship between drastic urban reorganization and public health, safety, convenience and welfare as soon as such reorganization gains sufficient public support to evoke legislative action. ${ }^{122}$

The political hurdle will be more formidable. Real estate investors and developers are pressure groups with great influence in municipal government. ${ }^{123}$ Public support for a program of urban reorganization must therefore be intense and effectively mobilized if it is to outweigh the opposition of groups financially damaged by a large-scale shift in land values. And after a general program has been adopted, active and effective public support may tend to want, while special group pressures will impinge with un-

ordinance. E.g., Ritenour v. Dearborn Tp., 326 Mich. 242, 40 N.W.2d 137 (1949); Reschke v. Village of Winnetka, 363 Ill. 478, 2 N.E.2d 718 (1936).

120. E.g., Village of Euclid v. Ambler Realty Co., 272 U.S. 365 (1926); West Bros. Brick Co. v. City of Alexandria, 169 Va. 271, 192 S.E. 881 (1937). And see BASSETT, ZoNING 46 (1936).

121. This result is common where the zoning classification in issue is at variance with the majority of the surrounding existing uses, either because neighboring property is in a different zone, see e.g., Bianchi v. Mory, 128 N.J.L. 219, 24 A.2d 566 (Sup. Ct. 1942); Reynolds v. Barrett, 12 Cal.2d 244, 83 P.2d 29 (1938), or because of neighboring non-conforming uses, see e.g., Taylor v. Village of Glencoe, 372 IIl. 507, 25 N.E.2d 62 (1940); Rowland v. City of Racine, 223 Wis. 488, 271 N.W. 36 (1937). But see Leventhal v. District of Columbia, 100 F.2d 94 (D.C. Cir. 1938) (zoning upheld despite "borderline" situation); Shepard v. Village of Skaneateles, 300 N.Y. 115, 89 N.E.2d 619 (1949) (zoning upheld despite surrounding non-conforming uses).

In sparsely built-up areas, on the other hand, a preponderance of non-conforming uses seems to be a less serious obstacle. See, e.g., Acker v. Baldwin, 18 Cal.2d 341, 115 P.2d 455 (1941); Stone v. Cray, 89 N.H. 483, 200 Atl. 517 (1938).

Some method of gradually eliminating non-conforming uses should weaken this objection to urban reorganization through zoning. Possible methods are the one adopted in Great Britain, namely, ordering immediate termination and compensating the owner, see note 32 supra, and the scheme adopted by a few American municipalities of ordering termination after giving the owner a reasonable period in which to amortize his investment, see note 99 supra.

122. A trend toward recognition of the broader type of planning as substantially related to public welfare has already set in. See, e.g., Acker v. Baldwin, 18 Cal.2d 341, 115 P.2d 455 (1941); Wilbur v. City of Newton, 332 Mass. 38,18 N.E.2d 365 (1938); Mansfield \& Swett Inc. v. Town of West Orange, 120 N.J.L. 145, 198 Atl. 225 (1938). And see WALKER, THE PlanNing FunCTION IN URBAN GOVERNMENT 80-5, 88-9 (1950).

For a less sanguine view of the readiness of courts to uphold zoning when used for urban reorganization see Tugwell, The Real Estate Dilemma, 2 PuB. AdMin. Rev. 27,35 (1942).

123. "Real estate speculators and developers are traditionally close to government. And property owners, even if they are conservative investors, are active in politics because they are subject to so many necessary regulations which they are always wanting modified or liberally interpreted." Id. at 30-1. And see Annual Report of the City Planning CoxMISSION OF NEW YORK 32 (1940). 
diminished force on every detailed measure implementing the program which has been accepted in principle.

Public ownership. If either of these obstacles should permanently block urban reorganization by regulation of private land use without compensation, extension of public ownership of land would provide a partial solution. Land in areas where the new pattern brings a radical reduction in values, such as prospective residential building land which is to be restricted to "greenbelt," or land held in the hope of intensive commercial use which is to be limited henceforth to open residential development, might be publicly acquired by condemnation. ${ }^{124}$ The public authority might then either redevelop it in accordance with the new pattern or resell it for regulated private development. ${ }^{125}$ Losses of land value in these areas would in both cases fall on the public authority instead of private owners; the result of the transaction from the public point of view would be analogous to payment of "compensation" without recovery of "betterment" elsewhere. ${ }^{126}$ Betterment might be recovered by acquiring and reselling other land whose value has increased because of the new land use pattern. ${ }^{127}$ Public acquisi-

124. For a discussion of such acquisitions as a solution to other planning problems than that of shifting value, see U.S. National Resources Planning Board, Public Land ACQuisition: URBAN LANDS 15-17 (1941).

125. Both practices are followed in present American urban redevelopment legislation. See Brown, Urban Redevelopment, 29 B.U.L. Rev. 318, 327-334 (1949); Comment, 44 ILL. L. REv. 685, 701 (1949).

126. E.g., purchase at the market price of land with a prospect of commercial development, followed by public development or resale to private developers for residential use, would involve the same loss to public authorities as would payment to owners for the loss in value caused by restriction to residential use. Such "compensation" does in fact occur when blighted land is purchased for redevelopment to residential use. See Brown, supra note 125, at 347-367.

127. Recent broadening of the concept of public use in eminent domain probably permits the use of this technique of collecting betterment. See Comment, 58 YALE L.J. 599 (1948).

Special assessment might be used as another device for recouping compensation expenditures. It is now used most frequently to finance municipal street construction, parks, and other improvements. 14 MCQuillen, Municipal Corporations $\$ \$ 38.12-38.29$ (1950). But the principle on which special assessment is based-"special . . . imposition on property in the immediate vicinity of a municipal improvement, which is necessary to pay for the improvement and is laid with reference to the special benefit which the property has derived therefrom . . . " Id. $\$ \$ 38.01-38.02$-should permit its application to neighboring property whose value is increased when, for example, a redevelopment project replaces a slum. Abandonment of the usual requirement that the property assessed must adjoin the improvement may even allow extension of special assessment to betterment resulting from shifting value.

A more accurate and just method of recovering betterment in order to balance compensation expenditure would be a tax levied on all annual increases in land value. Such a tax would draw not only upon increases traceable to shifting value, but also on increases arising from the effects of community planning in making land more desirable for its existing use, and on any increases due to increased demand for a particular use or to a general price rise. Since all increases would be covered, an amount sufficient eventually to balance compensation expenditures might be raised by a fairly small percentage levy. For a discussion 
tion for these purposes would require little departure from established American practice, ${ }^{128}$ and need be employed only at points where shifts in land value are drastic and the resultant obstacles to regulation impassable.

However, the principal defects of pre-1947 British compensation and betterment would also attach to these public acquisitions. All land acquired would have to be paid for at its market value, however inflated, since the "global sum" method of checking inflation can be applied only to an entire area of community growth. Experience in the United States with condemnation of "blighted" land in connection with recent redevelopment programs attests to the financial burden of such acquisition. ${ }^{129}$ The financial problem may not be insuperable if public acquisition is required only in a few instances to lubricate the path of regulation without compensation. But if extensive public acquisitions become necessary for this purpose, public payment for speculative private expectations of community expansion may render the cost of urban reorganization prohibitive.

The British solution. Adoption in the United States of the British method of public acquisition of all development rights in land might remove the obstacles to land use regulation raised by shifting land values. The "global" method of compensation would provide a standard for reduction of inflated development values, and the development charge would eventually make up for compensation expenditures. The development charge, if properly assessed, would also virtually eliminate the financial stake of particular landowners in community land use regulation. ${ }^{130}$ Charges could probably be assessed on the changes of land use covered by existing American types of regulation-i.e., a development charge would be levied whenever a building or occupancy permit was issued. But the danger that the British solution may destroy the profit incentive to private development militates especially against its adoption in the United States where private initiative is more heavily relied on for land development. Further experience in Great Britain is required for an estimate of the reality of this danger.

Even if it proves entirely successful in Great Britain, adaptation of this solution to American conditions would present other special problems. The acquisition of development rights would have to be carried out at least by an authority for a "metropolitan region," since the prospects of future land development are closely interrelated over a city, its suburbs and its potential

of this type of land value taxation, see Harriss, Alternative Bases for Real Estate Taxation, in Property Taxes 218, 219-25 (1940); U.S. National Resources Commitee, Urban Planning and Land Policies 307-309 (1939).

128. See pages 131-2 supra.

129. See Sen. Rep. No. 84, Feb. 25, 1949, 2 U.S. Code Cong. Serv. 1561 (1949); Brown, Urban Redevelopment, 29 B.U.L. REv. 318, 347-67 (1949).

130. By bringing about the purchase and sale of land at its existing use value, the development charge system might also eliminate much urban blight. Blight occurs partly because the price of land, based on the expectation, often unrealistic, of intensive commercial use, makes the maintenance of a desirable low density residential use unprofitable. See note 114 supra. When these expectations have ceased to drive up land values, private development of blighted areas for a desirable type of residential use may once more become feasible. 
suburbs. Authorities of this sort exist only in embryo in the United States. ${ }^{131}$ New administrative techniques would have to be established for assessing development values and fixing development charges, since existing municipal assessment is haphazard, ${ }^{132}$ and present judicial valuation proceedings are not geared to operate on a large scale. ${ }^{133}$ These techniques are particularly important to the success of the scheme because accuracy in setting development charges seems to be the crucial factor determining whether or not the British System will destroy private incentive. Furthermore, the constitutionality of the system would undoubtedly be questioned. Acquisition of development rights would be an unaccustomed addition to the category of "takings" by eminent domain. Most serious would be constitutional objections to compensation out of a "global sum," since "just compensation" in eminent domain proceedings has heretofore been equated with market value. ${ }^{134}$ But a convincing method of deriving the "global sum" from a reliably established rate of future development, bolstered by the argument that acquisition of development rights for an entire metropolitan region is different in kind from the "takings" with respect to which the market value rule was established, might support a special standard of "just compensation" in this instance.

\section{Conclusion}

The British Town and Country Planning Act of 1947 meets problems similar to those which will arise in the United States if more extensive urban reorganization becomes an accepted public policy. In most respects, American techniques for determining community design and regulating land use should prove as adequate for such reorganization as their British counterparts. However, existing American procedures provide no compensation for the effect of land use regulation in shifting land values, while under the Town and Country Planning Act public acquisition of development rights virtually neutralizes this effect. If American regulation is used for urban reorganization, its intensified impact will create judicial and political obstacles. The judicial obstacle could probably be overcome. The political obstacle might be overcome if general public support of urban reorganization were sufficiently strong and enduring. Strategic use of public ownership where the difficulties of regulation without compensation are most acute would help to reduce the political barrier. This course seems preferable in view of the difficulty of adapting the British solution to American conditions. However, if this program fails, public acquisition of development rights may offer an alternative.

131. See page 128 supra.

132. See Comment, Municipal Real Estate Taxation as an Instrument for Community Planning, 57 YALE L.J. 219, 222-3 and n. 16-26 (1947).

133. The value of land taken under eminent domain is usually a jury question. See Orgel, Valuation in EMinent Domain 30-35 (1936). A jury trial to fix development value in the case of each landowner who presents a claim for loss of development rights would probably tie up the courts for years, even if no other cases were heard. And see U.S. NAtional Resources Planning Board, op. cit. supra note 124, at 20-21.

134. See Orgel, Valuation in Eminent Domain 55-68 (1936) and cases cited. 